\title{
EVALUASI RUTE DAN HALTE BUS DI KOTA BANDUNG
}

\author{
Astri Mutia Ekasari \\ Program Studi Perencanaan Wilayah dan Kota, Fakultas Teknik, \\ Universitas Islam Bandung \\ Jl. Tamansari No. 1 Bandung, 40116
}

\begin{abstract}
ABSTRAK
Transportasi atau pengangkutan merupakan bidang kegiatan yang sangat penting dalam kehidupan masyarakat Indonesia khususnya transportasi darat. Transportasi darat merupakan moda yang paling dominan digunakan dibandingkan dengan moda transportasi lainnya. Berdasarkan Kebijakan pemerintah mengenai Bus sekolah gratis ini ternyata tidak memenuhi demand transportasi yang tinggi dari segi pendidikan. Jumlah pelajar yang menggunakan angkutan bus sekolah sebanyak 114.000 pelajar dari Januari 2014 hingga Maret 2014, jumlah pelajar ini tergolong sedikit tidak sesuai dengan jumlah demand yang ada. (Dishub Kota Bandung, 2014).

Analisis evaluasi rute yang digunakan adalah analisis untuk penilain kinerja pelayanan rute angkutan yang diperoleh berdasarkan literature dan standart yang ada dalam penilai rute angkutan Bis Sekolah.

Hasil Evaluasi menyimpulkan bahwa terdapat kinerja - kinerja rute yang tidak sesuai dengan satandart yang ada. Terdapat kesimpulan-kesimpulan penting dari penelitian ini. Untuk lebih jelasnya lihat dibawah ini : Jaringan Trayek yang ada tidak melayani kantung kantung perumahan, lokasi sekolah secara menyeluruh, Tidak adanya Halte khusus bus sekolah menyebabkan kebingungan calon penumpang untuk menaiki Bus Sekolah Tersebut, Jauhnya Akses Halte Menurut Penumpang dan $68 \%$ Pelajar jarang menggunakan layanan bus sekolah
\end{abstract}

Keyword : Rute, Halte Bus, Evaluasi

\section{Pendahuluan}

Manusia memiliki berbagai macam aktivitas yang sangat padat. Kebutuhan akan sarana transportasi terus meningkat sehingga menjadi suatu bagian yang tidak dapat dipisahkan dari masyarakat. Dalam kaitannya dengan kehidupan sehari-hari, transportasi memiliki peranan yang sangat signifikan dalam berbagai aspek seperti sosial, ekonomi, lingkungan, dan lain lain. Transportasi atau pengangkutan merupakan bidang kegiatan yang sangat penting dalam kehidupan masyarakat Indonesia khususnya transportasi darat. Transportasi darat merupakan moda yang paling dominan digunakan dibandingkan dengan moda transportasi lainnya. Oleh karena itu, masalah yang dihadapi hampir semua kota besar di Indonesia adalah kemacetan, polusi udara dan kesemrawutan lalu lintas. Secara umum kemacetan yang terjadi disebabkan oleh banyaknya kendaraan pribadi dan banyaknya pengoperasian angkutan umum yang tidak tertib.

Berdasarkan data dishub menunjukan bahwa kota-kota besar seperti Bandung termasuk dalam Kota termacet. Bandung memiliki tingkat kemacetan yang cukup tinggi di antara kota-kota lainya mencapai 0.85 VCR dengan kecepatan $14.3 \mathrm{Km} / \mathrm{Jam}$. Banyak faktor - faktor penyebab terjadinya kemacetan di Kota Bandung. Salah satu penyebab terjadinya kemacetan di Kota Bandung di 
sebabkan oleh tingginya tingkat Volume Lalulintas yang tidak sebanding dengan ruas jalan yang ada, dimana volume jumlah angkutan pribadi lebih besar di bandingkan dengan jumlah angkutan umum.

Volume Lalulintas di dominasi oleh Volume Jumlah angkutan pribadi sekitar 99\% dan $1 \%$ angkutan umum, dimana untuk angkutan pibadi $75 \%$ oleh kendaraan bermotor sebanyak 895 ribuan unit dan $24 \%$ oleh kendaraan mobil pribadi sebanyak 282 ribuan Unit. Untuk angkutan umum $0.6 \%$ oleh angkutan kota sebanyak 5.521 dan $0.4 \%$ oleh bus umum sebanyak 2.946 unit. Untuk penggunaan moda transportasi, masyarakat lebih memilih kendaraan pribadi, seperti sepeda motor (55,78 persen) dan mobil (30,96 persen). Pilihan terhadap angkutan umum hanya 13,25 persen. Fenomena ini menyebabkan tingkat kemacetan yang tinggi. (Dishub Kota Bandung, 2014)

Berdasarkan Kebijakan pemerintah mengenai Bus sekolah gratis ini ternyata tidak memenuhi demand transportasi yang tinggi dari segi pendidikan. Jumlah pelajar yang menggunakan angkutan bus sekolah sebanyak 114.000 pelajar dari Januari 2014 hingga Maret 2014, jumlah pelajar ini tergolong sedikit tidak sesuai dengan jumlah demand yang ada. (Dishub Kota Bandung, 2014).

Salah satu penyebab sepinya pelajar yang menggunakan Bus sekolah dikarenakan rute yang ada tidak melayani kantung kantung perumahan dan lokasi - lokasi sekolah secara keseluruhan, sehingga masih banyak pelajar yang tidak menggunakan angkutan Bus Sekolah.

Dalam buku (LPKM-ITB;1997) menyatakan bahwa Rute angkutan umum pada dasarnya menganut dua filisofi dasar, yaitu pendekatan efisiensi dan efektivitas. Ditinjau dari pendekatan efektivitas, maka filisofi mengenai rute dapat dinyatakan sebagai berikut: Rute yang baik adalah rute yang mampu menyediakan pelayanan semaksimal mungkin pada daerah pelayanannya kepada penumpang.

\section{Tujuan}

Tujuan dari penelitian ini adalah :
1. Untuk mengetahui apakah playanan Rute Bus Sekolah dan lokasi halte yang ada sudah mampu melayani kebutuhan demand akan transportasi dari segi pendidikan.

2. Untuk Menilai Kinerja Angkutan Bus Sekolah dari sisi Rute dan Halte.

\section{Metodologi}

\subsection{Metode Pengambilam Sampel}

Dalam Metode pengambilan sampel peneliti membatasi pengambilan sampel hanya dilakuakan di SMA Negri dengan status Cluster 1 hal ini disebabkan karena keterbatasan waktu yang ada sehingga dalam proses pengambilan sampel dipersempit. Hal yang melatar belakangi pengambilam sampel di SMA Negri dengan Cluster 1 dikarenan SMAN ini merupakan SMAN dengan minat terbanyak atau demand terbanyak. Dalam menentukan jumlah sampel yang di ambil di tiap SMAN ini mengunakan rumus berikut :

$$
s=\frac{\Lambda^{2} \cdot N \cdot P \cdot Q}{d^{2}(N-1)+\Lambda^{2} \cdot P \cdot Q}
$$

\footnotetext{
Keterangan:

$\mathrm{s}=$ Jumlah Sampel

$\Lambda^{2}=$ Chird Kuadrad yang harganya tergantung derajat kebebasan dan tingkat kesalahan. Untuk derajat kebebasan 1 dan kesalahan 5\% harga chi Kuadrad $=3,841$. Lihat tabel Chid Kuadrad

$\mathrm{N}=$ Jumlah Populasi

$\mathrm{P}=$ Peluang Benar ( 0,5)

$\mathrm{Q}=$ Peluang Salah $(0,5)$

$\mathrm{d}=$ Perbedaan Antara sampel yang diharapkan dengan yang terjadi perbedaan. Perbedaan bisa $1 \%, 5 \%$, dan $10 \%$
} 


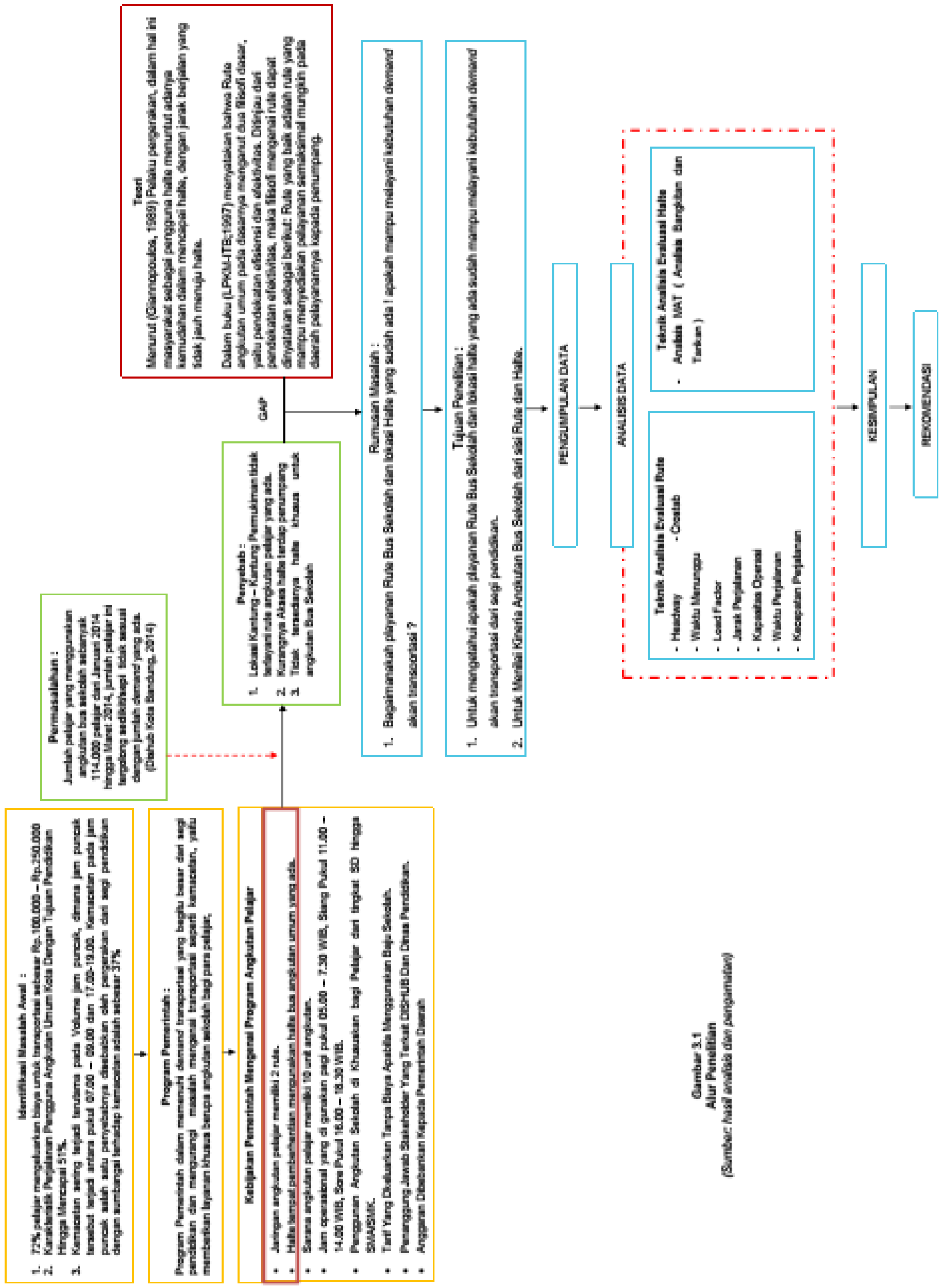

Page 44 
Analisis evaluasi rute yang digunakan adalah analisi untuk penilain kinerja pelayanan rute angkutan yang diperoleh berdasarkan literature dan standart yang ada dalam penilai rute angkutan Bis Sekolah

\section{a. Frekuensi Pelayanan}

$$
\begin{aligned}
& F=\frac{N}{K} \\
& 1 \quad \ldots \ldots \text { ensi (kendaraan/jam) } \\
& \mathrm{N} \quad=\quad \text { Besarnya permintaan untuk } \\
& \text { pelayanan (pnp/jam) } \\
& \mathrm{K}=\text { Jumlah penumpang maksimum per } \\
& \text { kendaraan (pnp/kendaraan) }
\end{aligned}
$$

b. Frekuensi berbanding terbalik dengan waktu antara (headway time), sedangkan waktu antara minimum dapat dihitung dengan rumus :

$\mathbf{H}=\mathbf{2} \mathbf{~ W t}$

Keterangan :

$\mathrm{H}=$ Waktu antara minimum antar

kendaraan (menit)

$\mathrm{Wt}=$ Waktu menunggu rata - rata (menit)

\section{c. Kapasitas Pelayanan}

$\mathbf{C t}=\mathbf{F} \times \mathbf{C a}$

Keterangan :

$\mathrm{Ct}=$ Kapasitas pelayanan

(penumpang/jam)

$\mathrm{Ca}=$ Kapasitas kendaraan

$\mathrm{F}=$ Frekuensi pelayanan

\section{d. Headway time(h)}

waktu antara keberangkatan satu kendaraan angkutan kota dengan kendaraan angkutan kota dibelakangnya pada suatu titik tertentu, atau selisih waktu kedatangan antara satu kendaraan dengan kendaraan berikutnya, biasanya pada bus stop satuan dalam (menit).

$\mathrm{h}=\mathbf{6 0} / \mathrm{f}$

dimana :

$\mathrm{h}=$ headway time(menit)

$\mathrm{f}=$ frekuensi $(\mathrm{kend} / \mathrm{jam})$ e. Kapasitas Kendaraan (Cv),

Kapasitas tempat duduk yang tersedia dan kapasitas tempat berdiri yang diizinkan pada satu kendaraan angkutan kota.

$\mathbf{C v}=\mathbf{C a}+\mathbf{a C b}$ (orang)

Dimana :

$\mathrm{Ca}=$ Kapasitas tempat duduk didalam

kendaraan

$\mathrm{Cb}=$ Kapasitas tempat berdiri di dalam

kendaraan

$\mathrm{a}=$ Faktor friksi yang diizinkan untuk tempat berdiri

\section{f. Load factor (LF)}

Rasio perbandingan antara jumlah penumpang yang diangkut dalam kendaraan terhadap jumlah kapasitas tempat duduk penumpang di dalam kendaraan pada periode tertentu.

$L f=\frac{\text { Jumlah penumpang yangdiangkut }}{\text { Kapasitas tempat duduk penumpang }} \times 100 \%$

g. Besarnya Pelayanan Angkutan (N)

Jumlah kendaraan yang dibutuhkan untuk melayani satu rute tertentu, dirumuskan:

$\mathrm{N}=$ To x f (Kendaraan) atau

$\mathrm{N}=\mathrm{To} / \mathrm{h}$ (kendaraan)

Tiga performansi pokok di dalam pelayanan angkutan, yaitu meliputi :

a. Headway time $(h)=\frac{60 \times L f C v}{P}$ (menit)

b. Load faktor $(L f)=\frac{P}{C v x \frac{60}{h}} \quad x \quad 100 \%$

c. Jumlah Kebutuhan Kendaraan Angkutan Kota :

$$
K=\frac{C T}{H \times f A}
$$

Dimana :

$\mathrm{K}$ = Jumlah Kendaraan $\mathrm{H}=$ Headway ( menit )

CT = Waktu Sirkulasi ( menit )

$\mathrm{fA}=$ Factor Ketersediaan Kendaraan ( 100

$\%)$ 
Hasil dan Analisis

Hasil pengamatan dapat dilihat pada peta peta dibawah ini.
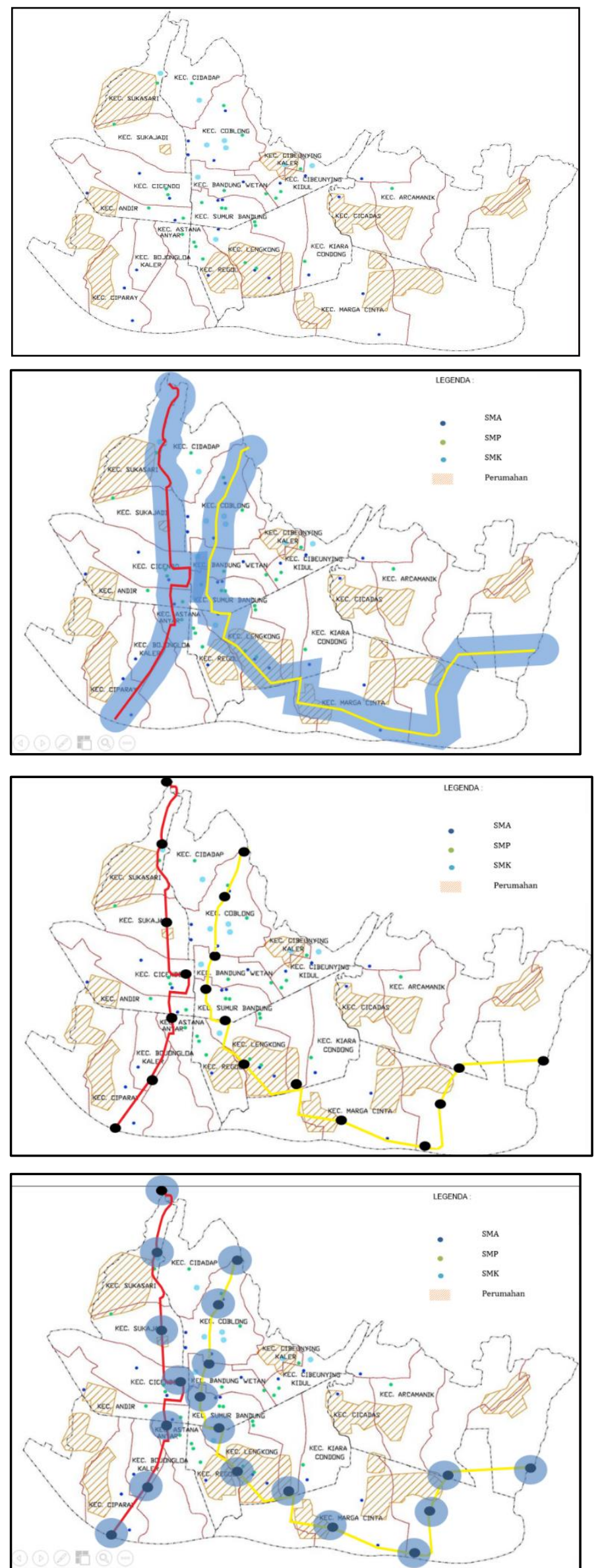

\section{Kesimpulan}

Berdasarkan penyebaran kuesioner terdapat berbagai pertanyaan - pertanyaa yang mendukung penilain terhadap rute dan halte bus. Berikut bentuk penrtayanyaa dan hasil :

A. Berapa Jumlah Pendapatan Orang Tua Sodara?
a. < Rp. 2.000.000
b. Rp $2.000 .000-$
Rp.4.000.000
c. Rp. 4.000 .000
8.000 .000
d. >Rp. 8.000 .000

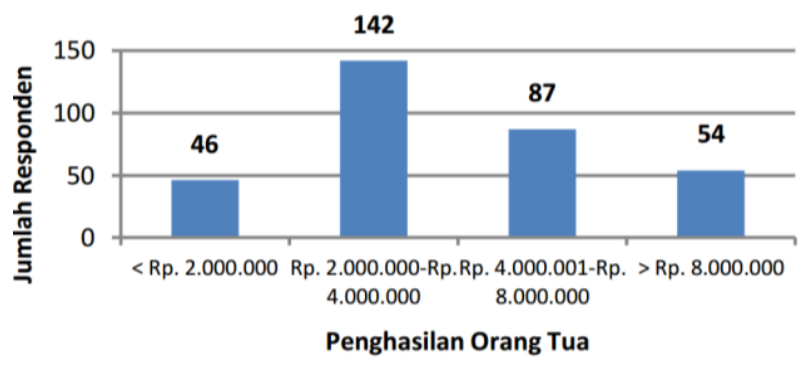

Berdasarkan penyebaran kuesioner di sekolahsekolah sampel penelitian, terdapat variasi tingkat pendapatan orang tua pelajar di masingmasing sekolah. Hal ini menunjukkan adanya perbedaan tingkat ekonomi di masing-masing sekolah. Namun secara umum, tingkat pendapatan orang tua pelajar berdada pada kelompok pendapatan Rp. 2.000.000,00-Rp. 4.000.0000,00.

B. Apakah Sodara Memiliki Kendaraan Pribadi?

a. Tidak Memiliki Kendaraan Pribadi b. Memiliki Motor c. Memiliki Mobil d. Memiliki Mobil dan Motor

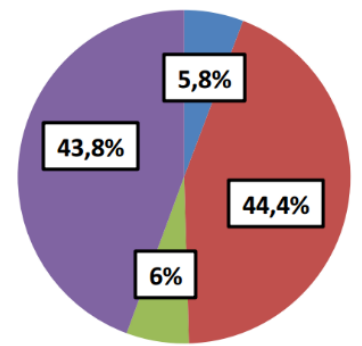

$$
\begin{aligned}
& \text { Tidak Memiliki } \\
& \text { Kendaraan Pribadi } \\
& \text { Memiliki Motor } \\
& \text { Memiliki Mobil } \\
& \text { Memiliki Mobil dan } \\
& \text { Motor }
\end{aligned}
$$

Kepemilikan kendaraan pribadi sangat tinggi. Hanya terdapat 5,8\% keluarga pelajar yang tidak memiliki kendaraan pribadi. Untuk kepemilikan kendaraan, sebesar $43,8 \%$ dari keluarga pelajar, dan sebesar $6,1 \%$ memiliki mobil sebagai moda transportasinya. Sebagian besar keluarga 
pelajar, yaitu sebesar $44,4 \%$ keluarga pelajar memiliki mobil dan motor untuk keperluan pergerakannya.

C. Setelah Pualang Sekolah Apakah sodara langsung pulang ke rumah ?

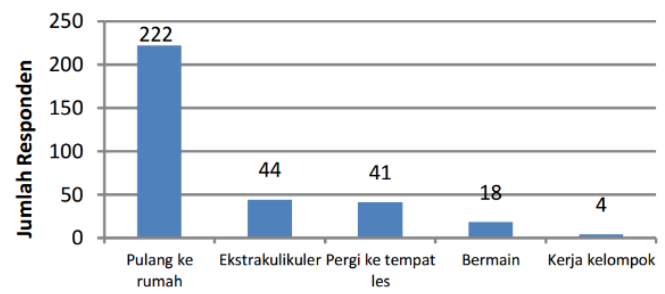

Sebagian besar pelajar langsung pulang ke rumah setelah kegiatan sekolah berakhir. Sebesar 67,5\% langsung pulang ke rumah masing-masing selepas sekolah. Sedangkan untuk kegiatan lainnya, sebanyak 20,1\% melakukan ekstrakulikuler, bermain, dan kerja kelompok yang dilakukan di sekolah setelah kegiatan belajar mengajar berakhir. Kegiatan lainnya adalah pergi ke tempat les, sebanyak $12,5 \%$ yang dilakukan di luar sekolah.

D. Apakah Sodara sudah pernah menaiki Bus Sekolah ?

a. Jarang b. Kadang - Kadang c. Sering d. Selalu

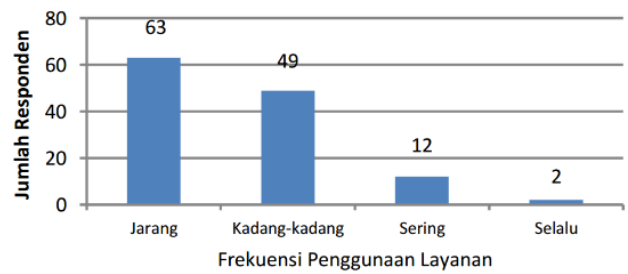

Berdasarkan hasil penyebaran kuesioner, terdapat $9 \%$ pelajar yang belum mengetahui adanya layanan bus sekolah gratis. Selain itu, bus sekolah baru digunakan oleh $38 \%$ pelajar dari sekolah sampel penelitian, dan $68 \%$ diantaranya jarang menggunakan layanan bus sekolah.

E. Apa Alasan Sodara jarang dan tidak pernah menggunakan angkutan Bus Sekolah ?

Berdasarkan pengolahan data mengenai alasan pelajar tidak pernah dan jarang menggunakan layanan bus sekolah, alasan terbanyak yang diberikan oleh pelajar adalah karena lokasi rumahnya tidak dilalui oleh layanan bus sekolah. Persentase pelajar yang memberikan alasan ini mencapai $78,2 \%$. Sedangkan alasan-alasan lain yang diberikan adalah sebesar 25,2\% menyatakan akses menuju halte/pick up point terlalu jauh, dan sebesar $24,2 \%$ menyatakan waktu operasional bus sekolah tidak sesuai kebutuhan. Alasan-alasan yang banyak diberikan oleh pelajar adalah terkait dengan operasional bus sekolah yang tidak sesuai dengan kebutuhan dan keinginan pelajar. Beriku table hasil quisioner :

\begin{tabular}{|c|c|c|c|c|}
\hline \multirow{2}{*}{ Alasan } & \multicolumn{2}{|c|}{ Ya } & \multicolumn{2}{|c|}{ Tidak } \\
\hline & $\begin{array}{l}\text { Juml } \\
\text { ah }\end{array}$ & $\%$ & $\begin{array}{l}\text { Juml } \\
\text { ah }\end{array}$ & $\%$ \\
\hline $\begin{array}{l}\text { Tempat tinggal tidak } \\
\text { dilalui bus sekolah }\end{array}$ & 208 & $78,2 \%$ & 58 & $21,8 \%$ \\
\hline $\begin{array}{l}\text { Akses menuju pick } \\
\text { up point/halte jauh }\end{array}$ & 67 & $25,2 \%$ & 199 & $74,8 \%$ \\
\hline $\begin{array}{l}\text { Waktu operasi tidak } \\
\text { sesuai jam sekolah }\end{array}$ & 65 & $24,4 \%$ & 201 & $75,6 \%$ \\
\hline $\begin{array}{l}\text { Lokasi naik turun } \\
\text { bus tidak jelas }\end{array}$ & 60 & $22,6 \%$ & 206 & $77,4 \%$ \\
\hline $\begin{array}{c}\text { Menunggu bus } \\
\text { terlalu lama }\end{array}$ & 59 & $22,2 \%$ & 207 & $77,8 \%$ \\
\hline $\begin{array}{c}\text { Lebih senang } \\
\text { menggunakan } \\
\text { kendaraan pribadi }\end{array}$ & 46 & $17,3 \%$ & 220 & $82,7 \%$ \\
\hline $\begin{array}{c}\text { Waktu perjalanan } \\
\text { menggunakan bus } \\
\text { terlalu lama }\end{array}$ & 13 & $4,9 \%$ & 253 & $95,1 \%$ \\
\hline $\begin{array}{c}\text { Tidak diizinkan } \\
\text { orang tua }\end{array}$ & 7 & $21,6 \%$ & 259 & $97,4 \%$ \\
\hline Merasa tidak aman & 4 & $1,5 \%$ & 262 & $98,5 \%$ \\
\hline $\begin{array}{c}\text { Merasa tidak } \\
\text { nyaman }\end{array}$ & 4 & $1,5 \%$ & 262 & $98,5 \%$ \\
\hline $\begin{array}{c}\text { Gengsi } \\
\begin{array}{c}\text { menggunakan bus } \\
\text { sekolah }\end{array}\end{array}$ & 3 & $1,1 \%$ & 263 & $98,9 \%$ \\
\hline $\begin{array}{l}\text { Sumber: Hasil Analisi } \\
\text { berapa lama } \\
\text { Sekolah Ter }\end{array}$ & ut ? & & 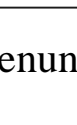 & $\mathrm{u}$ Bus \\
\hline
\end{tabular}
a. 5 Menit b. 10 Menit
c. 15 Menit d. 20 Menit e. 30 Menit

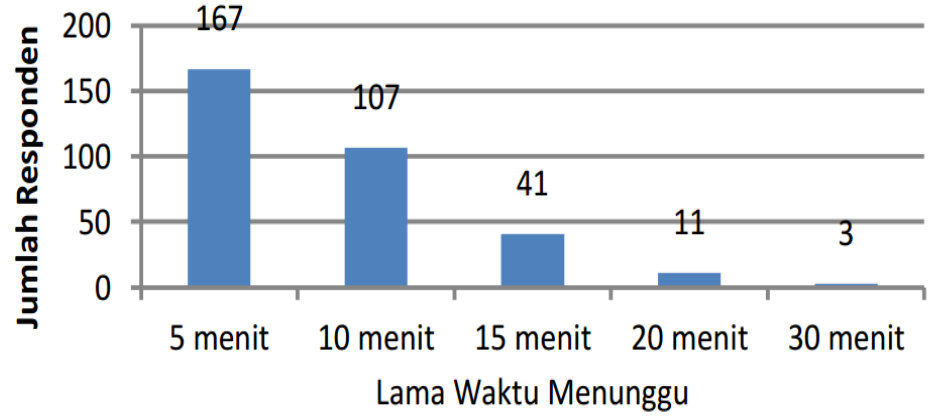


Apabila ditinjau dari akses terhadap bus sekolah, kesediaan pelajar untuk menunggu bus sekolah adalah 5-10 menit, dan akses dari rumah dan sekolah menuju layanan bus sekolah atau lokasi pemberhentian bus sekolah adalah 100 meter.

G. Apabila anda menggunakan Bus Sekolah berapa lama ketersediaan menunggu Bus Sekolah Tersebut dalam Lokasi Pemberhentian?
a. $100 \mathrm{~m}$
b. $200 \mathrm{~m}$ $1000 \mathrm{~m}$

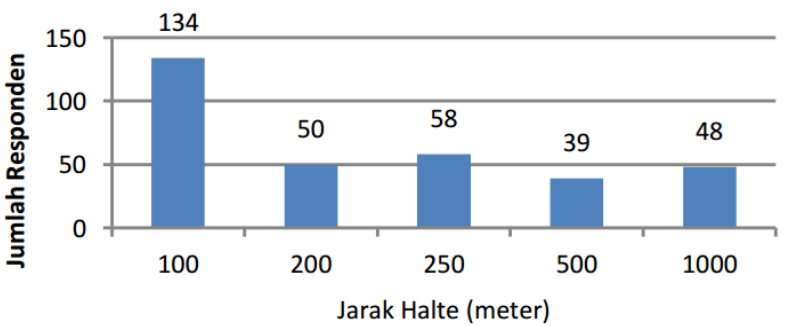

H. Apabila anda menggunakan Bus Sekolah berapa lama ketersediaan dalam Waktu Perjalanan?

\begin{tabular}{lrrrrrrr}
\hline \multirow{2}{*}{ Jarak } & \multicolumn{9}{c}{ Lama Perjalanan Maksimal (menit) } & \multirow{2}{*}{$\begin{array}{c}\text { Jumlah } \\
\text { Pelajar }\end{array}$} \\
\cline { 2 - 6 } & 10 & 20 & 30 & 40 & 50 & 60 & \\
\hline $1-5 \mathrm{~km}$ & 93 & 79 & 24 & 0 & 0 & 0 & 196 \\
\hline $6-10 \mathrm{~km}$ & 24 & 38 & 20 & 8 & 0 & 0 & 90 \\
\hline $11-15 \mathrm{~km}$ & 4 & 11 & 10 & 1 & 2 & 4 & 32 \\
\hline $16-20 \mathrm{~km}$ & 0 & 1 & 1 & 0 & 1 & 1 & 4 \\
\hline$>20 \mathrm{~km}$ & 0 & 1 & 3 & 1 & 1 & 1 & 7 \\
\hline Sumbrnnnnnnnn
\end{tabular}

Kesediaan pelajar untuk melakukan perjalanan menggunakan layanan bus sekolah adalah 10-20 menit untuk kelompok jarak perjalanan 1-5 km. Sedangkan pada kelompok jarak perjalanan 6-10 km, ratarata pelajar bersedia melakukan perjalanan selama 20 menit dan maksimal 40 menit. Pada kelompok perjalanan 11-15 $\mathrm{km}$, rata-rata pelajar bersedia melakukan perjalanan selama 20-30 menit dengan maksimal waktu perjalanan 60 menit. Sedangkan pada perjalanan jarak jauh, yaitu diatas $15 \mathrm{~km}$, ratarata pelajar bersedia melakukan perjalanan selama 30 menit.
Hasil

Hasil Evaluasi menyimpulkan bahwa terdapat kinerja - kinerja rute yang tidak sesuai dengan satandart yang ada. Terdapat kesimpulan-kesimpulan penting dari penelitian ini. Untuk lebih jelasnya lihat dibawah ini :

$>$ Jaringan Trayek yang ada tidak melayani kantung kantung perumahan, lokasi sekolah secara menyeluruh

$>$ Tidak adanya Halte khusus bus sekolah menyebabkan kebingungan calon penumpang untuk menaiki Bus Sekolah Tersebut

$>$ Jauhnya Akses Halte Menurut Penumpang

$>68 \%$ Pelajar jarang menggunakan layanan bus sekolah

> Kondisi Rute dan Halte yang ada tidak mampu melayani Kebutuhan Akan transportasi

$>$ Kinerja Rute dan halte yang buruk

\section{Rekomendasi}

Rekomendasi dibuat untuk menjawab dari hasil kesimpulan. Rekomendasi ini dibuat untuk memperbaiki hasil analisis yang berdampak buruk. Untuk lebih jelasnya sebagai berikut :

$>$ Perlu adanya penentuan Rute dan Penambahan Rute

$>$ Perlu Adanya Penyediaan Halte Khusus Bus Sekolah untuk calon penumpang

$>$ Perlu Adanya Peningkatan kinerja Rute dan halte agar menintkatkan Demand dari pergerkan pendidikan

\section{Daftar Pustaka}

Ir.Edy Sutiono, MT dan DR. Ir. Sigit Priyanto. 2000. Evaluasi Rute angkutan Umum Kawasan Kampus Ugm Yogyakarta. Jurnal Simposium III FSTPT, ISBN no. 979 -96241-0-X

Nika Devi Permata Wijaya dan Delisa Prita Dinanti.2015. Studi Evaluasi Pengoperasian Bus Sekolah Gratis Di Kota Blitar. 
Amilatush Sholichah dan Sardjito. 2012. Penentuan Rute Angkutan Umum Berbasis Transport Network Simulator di Kecamatan Candi dan Kecamatan Sidoarjo Kabupaten Sidoarjo. Jurnal Teknik Pomits Vol. 3, No. 2, (2014) ISSN: 2337-3539

Angga Nursita Sari. 2008. Evaluasi Rute Trayek Angkutan Umum Penumpang (Aup) Berdasarkan Persebaran Permukiman Di Kabupaten Sragen.

Susanto. 2005. Analisis Kebutuhan dan Pemilihan Lokasi Halte di Pintu Tol Padalarang.

Amin Budiman. 2009. Konsep Struktur Kota Dan Persebaran Fasilitas Pendidikan Dalam Penentuan Rute Angkutan Sekolah Di Kota Banda Aceh.

Rudi Yuniarto Adi. 2006. Analisa Kinerja Pelayanan Angkutan Bus Sedang Jurusan Bukit Kencana - Mangkang.

Fajar Anasrul Laksmianto. 2010. Analisis Finansial Rencana Pengoperasian Angkutan Sekolah Malang International Education Park Di Kota Malang. Jurnal Studi Ekonomi Indonesia Fakultas Ekonomi Universitas Sebelas Maret.

Andruska dan Patoyo Kusumantoro. 2013. Potensi Pengembangan Layanan Bus Sekolah di Daerah Perdesaan (Studi Kasus: Trayek Muaro Sijunjung Padang Sibusuk, Kabupaten Sijunjung, Sumatera Barat). Jurnal Perencanaan Wilayah dan Kota B SAPPK V4N1.

Oktavianus Wijaya Ardhya Kusuma. 2015. Evaluasi Program Bus Sekolah Di Kota Surabaya. Jurnal SSN 2303 - 341X Volume 3, Nomor 2.

Dhanisa Rifky Firmanda dan Noorhadi Rahardjo. 2013. Sistem Informasi Geografi Untuk Evaluasi Lokasi Shelter Bus Trans Semarang.

Raisa Zuhria Savitri dan Miming Miharja. 2015. Identifikasi Kebutuhan Pengembangan Layanan Bus Sekolah Gratis Kota Bandung Studi Kasus: Trayek BS-01 Antapani-Ledeng. Jurnal Perencanan Wilayah dan Kota A SAPPK V4 N2.
Departement of Education \& training Public Transport Victoria. November 2013. School Bus Program Policy and Procedures.

Selecting School Bus Stop Locations: A Guide for School Transportation Professionals. 2010.

The National Highway Traffic Safety Administration U.S. Department of Transportation. 1998. Identification and Evaluation Of School Bus Route and Hazard Marking Systems. Jurnal Grant \# DTNH22-97-G-05155. 